\title{
Development and characterization of a novel standardized propolis dry extract obtained by factorial design with high artepillin C content
}

Flávia Silva Marquiafável' , Andresa Piacezzi Nascimento', Hernane da Silva Barud ${ }^{3}$, Franciane Marquele-Oliveira', Luís Alexandre Pedro de Freitas ${ }^{2}$, Jairo Kenupp Bastos ${ }^{2}$ and Andresa Aparecida Berretta ${ }^{1,2^{*}}$

*Correspondence: andresaberretta@hotmail.com

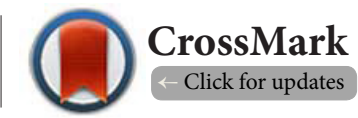

${ }^{1}$ Research Laboratory, Development and Innovation (RD \& I)-Apis Flora Industrial and Commercial LTD, Brazil. ${ }^{2}$ Department of Pharmaceutical Sciences, School of Pharmaceutical Sciences of Ribeirao Preto, University of Sao Paulo, Brazil.

${ }^{3}$ Medicinal Chemistry Laboratory and Regenerative Medicine (QUIMMERA)-University Center of Araraquara, Brazil.

\begin{abstract}
Background: Besides the known propolis biological activities, widely reported in many scientific studies, new findings in animal models have opened new fields for propolis application. Recently, there has been an increased interest in dried extracts based on natural products including propolis, as the product in the dry presentation shows several advantages. Therefore, standardizing a more soluble dry extract and allowing the production of human dosage forms are of great interest. In this context, this work aimed to develop a propolis dry extract with high propolis and artepillin C contents.

Methods: The experiments followed a Box-Behnken design to study the effects of the process on the physicochemical properties of the powder using a spray drying equipment. The following drying excipients were used: silicon dioxide with arabic gum (encapsulating system A) and modified starch (encapsulating system B). Furthermore, physicochemical characterization, particle morphology by scanning electron microscopy and antibacterial assay of the samples were carried out.

Results: The results revealed that all variables of the process did not influence significantly propolis and flavonoid content, moisture and angle of repose in the encapsulating system A (arabic gum and silicon dioxide). For the encapsulating system B (modified starch and silicon dioxide), it was observed that the propolis content, flavonoid content, density, moisture and angle of repose were influenced significantly by the variables of the drying process parameters. Finally, p-coumaric acid, cinnamic acid and artepillin $\mathrm{C}$ were affected by the process conditions of system $\mathrm{A}$, while, these biomarkers were not affected by the encapsulating system B. Both propolis dry extracts obtained were active against Staphylococcus aureus.

Conclusions: This study evidenced different encapsulating systems lead to different effects, depending on the drying process parameters. Both encapsulating systems allowed to obtain a standardized propolis extract with high flavonoid content and the expected amounts of artepillin C. Also, they maintained the antibacterial activity of propolis.
\end{abstract}

Keywords: Propolis dry extract, factorial design, artepillin C, standardized propolis extract, antibacterial activity

\section{Introduction}

Propolis, a resinous substance produced by honey bees from exudates collected from different parts of the plants, has been used for centuries in folk medicine due to its therapeutic properties [1]. Propolis is used by the bees to control the growth of microorganisms [2], and it displays several other bioactivities, such as antiviral $[1,3]$, anti-inflammatory [4-6], antioxidant [7,8], antiparasitic $[9,10]$, wound healing and antifungal $[11,12]$.

Besides the above mentioned biological activities, widely reported in many scientific studies, new findings may also open new fields for propolis application. Chen et al., [13] suggested the potential for propolis employment as a protector

(C) 2015 Berretta et al; licensee Herbert Publications Ltd. This is an Open Access article distributed under the terms of Creative Commons Attribution License (http://creativecommons.org/licenses/by/3.0). This permits unrestricted use, distribution, and reproduction in any medium, provided the original work is properly cited. 
Marquiafável et al. Journal of Pharmaceutical Technology \& Drug Research 2015,

of the brain in elderly, in preventing Alzheimer's and other neurodegenerative diseases. Some studies suggested propolis as a possible product for the treatment of diabetes mellitus, since propolis displays antidiabetic and hypolipidemic effects [14] including interesting results in ob/ob mice at $100 \mathrm{mg} /$ kg i.p. [15]. Probably, artepillin C, one of the major green propolis compounds directly binds to PPARy receptor, inducing adipocyte differentiation and glucose uptake in in vitro model $(1,3,10$ and $30 \mu \mathrm{M})$, which could be the basis of the pharmacological benefits of green propolis intake in reducing the risk of type 2 diabetes [16].

Barros et al., [17] reported that the hydroalcoholic green propolis extract $(50,250$ and $500 \mathrm{mg} / \mathrm{kg} /$ day), characterized in artepillin C content, diminished gastric ulcer in Wistar rats and significantly reduced the parameters evaluated in gastric ulceration. This animal dosage, when extrapolated to human, results in the propolis dry matter ingestion of 56.4 to 564.5 $\mathrm{mg} /$ day/adult, using like a safety factor the relation $1 / 10$ as suggested by FDA Safety Guideline. The antiulcer effects observed was due to caffeic, ferulic, $p$-coumaric and cinnamic acids, in the concentrations of 50 and $250 \mathrm{mg} / \mathrm{kg} / \mathrm{day}$ [18]. Based on the beneficial effects that propolis may bring to human health, several discussion groups are taking place worldwide to disclose approved laws for the medicinal use of propolis. Such an example is the EMEA in Europe, which through Herbal Medicinal Products Committee (HMPC) is in an advanced process of discussion to standardize the law. They have already submitted for approval by the European Parliament the inclusion of propolis and other products, like an extension of "Directive 2001/83 / EC" to an existing products record of plant origin. Finally, it is worth noting the consolidated Canadian law [19], in which propolis figures as an oral use antioxidant and anti-inflammatory agent at suggested dosages of 0.2 to $0.6 \mathrm{~g}$ propolis per day.

It should be noted that to obtain products to be marketed as functional foods or medicines, the same chemical composition must be established and standardized in order to do not lose the established studies on safety and efficacy. Additionally, standardization is necessary for the batch-to-batch reproducibility in future productions $[11,20]$. Such requirement is usually a commonly asked item by regulators when registering active ingredients of natural origin. The selection of the biomarker for propolis extracts would not only depend on the therapeutic focus, but also on other issues, as reports regarding isolated compounds, as well as, reports matching the marker with the desired activity.

Recently, there has been an increased interest in dried extracts of natural products, including propolis [21-25]. In the pharmaceutics, agrochemical and food development areas, the standardization, as well as, the powder form present several advantages. Increased concentration of propolis dry matter, chemical stability of the compounds, longer preservation of the biological properties could be named. Additionally, the production of products in the form of powders, i.e., sachets, and tablets and capsules [26], presentations with higher compliance in therapeutics, could be reached. Besides the stated advantages regarding the pharmaceutical dosage forms, the drying process may also involve biopharmaceutical considerations with the encapsulation of the product. Micro/ nano encapsulation systems also provide advantages, such as minimized sensory flavor and odor, as well as, controlled release of the active compounds.

Several processes for drying and encapsulation of natural products have been reported. Choosing the best one will depend on the type of material to be encapsulated, and the release mechanism required for its action. Spray drying is extensively employed in the pharmaceutical industry for the production of drugs and excipient or as a microencapsulation process. This technique turns the fluid sample in a dry powder in one step, and, it can be applied to a wide variety of materials. Drawbacks, as low yield, material adhesiveness and high moisture, may be avoided by well controlled process variables. Optimization of spray drying process involves both the evaluation of the parameters related to drying and formulation composition that will feed the system [27].

Besides the regular drawbacks involved in obtaining natural dry extracts, propolis per se presents particular challenges. Several studies have been performed trying to overcome these challenges, but propolis content in the final dry extract is still an important concern. Recently, Da Silva et al., [24] employed arabic gum and octenyl succinic anhydride (OSA) starch as carriers to obtain spray-dried propolis extract. The process allowed obtaining propolis in the powder form with preserved antioxidant activity. It also demonstrated stability during storage at room temperature, had low hygroscopicity and was highly dispersible in cold water. On the other hand, propolis:excipient ratio was set at 1:4 or 1:6, a relatively low concentration, when considering solid dosage forms.

Based on the described advantages provided by using standardized propolis powder extracts along with the need for worldwide market release of this kind of propolis presentation, in this work we are reporting the preparation, comprehensive characterization and efficacy of a novel enriched propolis and artepillin C dried extract. Factorial design was employed to obtain dry extract containing $50 \%$ of propolis dry mater employing modified starch:silicon dioxide (1:1) and arabic gum:silicon dioxide (1:1) as encapsulating systems by spray-drying.

\section{Materials and methods Materials}

Green propolis standardized extract (EPP-AF ${ }^{\circ}$ ) was kindly provided by Apis Flora Co. (Ribeirão Preto, São Paulo, Brazil) (Patent PI 0405483-0, Revista de Propriedade Industrial No. 1778 of $01 / 02 / 2005)$. This extract contains $11 \% \mathrm{w} / \mathrm{v}$ of propolis dry matter, $57 \%$ of ethanol, $23.19 \pm 0.091 \mathrm{mg} / \mathrm{g}$ of total phenol content (expressed in gallic acid) and $5.489 \pm 0.240 \mathrm{mg} / \mathrm{g}$ of total flavonoid content (expressed in quercetin). The HPLC chromatographic analysis allowed the quantification of: $0.296 \pm 0.005$ 
$\mathrm{mg} / \mathrm{g}$ of caffeic acid, $1.469 \pm 0.037 \mathrm{mg} / \mathrm{g}$ of $p$-coumaric acid, $0.147 \pm 0.003 \mathrm{mg} / \mathrm{g}$ of cinnamic acid, $0.834 \pm 0.045 \mathrm{mg} / \mathrm{g}$ of aromadendrin, $2.402 \pm 0.054 \mathrm{mg} / \mathrm{g}$ of isosakuranetin, $6.260 \pm$ $0.176 \mathrm{mg} / \mathrm{g}$ of artepillin C and $0.039 \pm 0.001 \mathrm{mg} / \mathrm{g}$ of baccharin.

Artepillin C (Wako Pure Chemical Industries Co., Osaka, Japan) and aromadendrin-4'-O-methyl ether (previously isolated and identified as described by Souza et al., [26] and kindly donated by the authors), caffeic, $p$-coumaric and cinnamic acids (Sigma-Aldrich, São Paulo, Brazil) were employed for quantitative analysis by HPLC. Methanol HPLC-grade was obtained from J.T. Baker and water was treated in a Milli-Q water purification system. All other chemicals were of reagent grade and were used without further purification. To obtain the dried extracts, colloidal silicon dioxide (Aerosil 200, Degussa, Dusseldorf, Germany), Arabic gum (Synth, Brazil) and modified starch (Capsul', National Starch and Chemical Co. Bridgewater, NJ, USA) were assessed. Mueller Hinton agar and Mueller Hinton broth (Difco, Detroit, MI, USA), were used for the antimicrobial assays.

\section{Methods \\ Spraydrying}

The drying excipients, silicon dioxide with arabic gum (encapsulating system A) or modified starch (encapsulating system B), were directly dispersed in the EPP-AF and were maintained under constant agitation for 1 hour. Arabic gum had to be firstly dispersed in water. The ratio between excipient and propolis dry matter was set at a 1:1, equivalent to $50 \%$ of propolis in the final powder. Spray drying of the extract was conducted using a laboratory-scale spray dryer (model MSD 0.5, Labmaq do Brasil Ltda, Ribeirão Preto, Brazil). This is a benchscale apparatus with a drying chamber and cyclone made of borosilicate glass, pneumatic (two-fluid) spray nozzle, an air inlet temperature indicator, and digital control of the drying air flow rate and outlet temperature. The borosilicate glass drying chamber has a diameter of $135 \mathrm{~mm}$ and length of $510 \mathrm{~mm}$ and the maximum water evaporation capacity is $0.5 \mathrm{~L}$ per hour. The pneumatic spray nozzle has an orifice of $1.0 \mathrm{~mm}$ in diameter.

The following spray operational conditions were kept constant during spray drying process and the values were designed by factorial designer: extract feed rate $(6-12 \mathrm{~mL} /$ $\mathrm{min})$, drying air flow rate $\left(2-3 \mathrm{~m}^{3} / \mathrm{min}\right)$ and sample outlet temperature $\left(60-100^{\circ} \mathrm{C}\right)$.

\section{Factorial design}

The study followed a Box-Behnken design, and the influence of sample outlet temperature, sample flow (extract feed rate) and air flow in the system (air flow rate) on the dried extracts properties was investigated. The influence of these factors on the characteristics of the dry powder was evaluated by (i) physicochemical parameters: propolis and flavonoid content, density, moisture, yielding and some flow characteristics: Carr index, Hausner factor and angle of repose, and (ii) artepillin C content and chemical profile. The Box-Behnken design allowed the determination of linear, quadratic, and interactive effects [28] (Table 1). By the program Statistica version 7, statistical analysis (ANOVA) and analysis of response surface were performed for the studied parameters. Particle morphology and antimicrobial activity were assessed with a representative samples of each encapsulating system.

Table 1. Experimental design using Box-Behnken. Demonstration of the studied factors and their levels.

\begin{tabular}{lccclll}
\hline Experiment & X1 & X2 & X3 & Temperature & ExtrFR $^{*}$ & AirFR $^{\dagger}$ \\
\hline 1 & -1 & -1 & 0 & 60 & 6 & 2.5 \\
2 & 1 & -1 & 0 & 100 & 6 & 2.5 \\
3 & -1 & 1 & 0 & 60 & 12 & 2.5 \\
4 & 1 & 1 & 0 & 100 & 12 & 2.5 \\
5 & -1 & 0 & 1 & 60 & 9 & 3 \\
6 & 1 & 0 & -1 & 100 & 9 & 2 \\
7 & -1 & 0 & 1 & 60 & 9 & 3 \\
8 & 1 & 0 & 1 & 100 & 9 & 3 \\
9 & 0 & -1 & -1 & 80 & 6 & 2 \\
10 & 0 & 1 & -1 & 80 & 12 & 2 \\
11 & 0 & -1 & 1 & 80 & 6 & 3 \\
12 & 0 & 1 & 1 & 80 & 12 & 3 \\
13 & 0 & 0 & 0 & 80 & 9 & 2.5 \\
14 & 0 & 0 & 0 & 80 & 9 & 2.5 \\
15 & 0 & 0 & 0 & 80 & 9 & 2.5 \\
\hline
\end{tabular}

${ }^{*}$ ExtrFR: Extract feed rate; ${ }^{\dagger}$ AirFR: Air flow rate

\section{Physicochemical characterization Propolis content determination (PC)}

Propolis content $(\mathrm{PC})$ was determined by the extraction of the sample followed by the determination of its density (d) and soluble solids (SS). For such assessment, one gram of the dry extract of propolis was weighed into a $15 \mathrm{~mL}$ Falcon tube, added with $8 \mathrm{~mL}$ of ethanol $\left(96^{\circ} \mathrm{GL}\right)$, sonicated for 10 minutes, followed by centrifugation at $3500 \mathrm{rpm}$ for 10 minutes and the separation of the supernatant. Exhaustive extraction was performed ( 6 times) and supernatants were pooled and adjusted to $50 \mathrm{~mL}$ (vf) with ethanol $96^{\circ} \mathrm{GL}$. This sample was assessed regarding soluble solids determination (SS).

\section{Flavonoid content determination}

For flavonoid content in the dry extracts, the Aluminium Chloride method was employed as described by Woisky and Salatino [29]. The results were expressed as quercetin equivalent $(\mathrm{mg} / \mathrm{g})$.

\section{Drying process yielding}

To $100 \mathrm{~mL}$ of EPP-AF (equivalent to $11.1 \mathrm{~g}$ of dry material) it was added $5.55 \mathrm{~g}$ of silicon dioxide and $5.55 \mathrm{~g}$ of arabic gum 
or $5.55 \mathrm{~g}$ of modified starch, resulting in $22.2 \mathrm{~g}$ of theoretical mass. The yield $(\mathrm{Y})$ was calculated as:

$\mathrm{Y}=$ Mass of the powdered after dryingX100/ Theoretical mass

\section{Determination of powder flowability}

To assess powder flowability, Carr index, Hausner factor and angle of repose were evaluated.

For the determination of Bulk Apparent Density (BAD), 2 $\mathrm{g}$ of powder was placed in a $10 \mathrm{~mL}$ measuring cylinder. The volume was recorded, and bulk apparent density was determined. The result was used to calculate the Carr Index and Hausner factor.

\section{$\mathrm{BAD}=$ Powder mass/Not compacted volume}

The determination of Carr Index $(\mathrm{Cl})$ and the Hausner Factor(HF) was assessed by the formulas:

$\mathrm{CI}=(\mathrm{D}-\mathrm{BAD}) \mathrm{X} 100 / \mathrm{BAD}$

$$
\mathrm{HF}=\mathrm{D} / \mathrm{BAD}
$$

where $\mathrm{D}$ is the Apparent Density (powder mass/compacted volume).

Values below 15 for Carr index indicate excellent fluidity. However, Carr index values above 20 show a weak flow [30]. In relation to the Hausner factor, values greater than 1.25 have poor flowability [31].

The determination of the angle of repose $\left(a^{\circ}\right)$ involves the use of a plastic funnel fixed on a base timber according to the specifications [32]. Four grams of sample were transferred while the lower end was blocked. Below the lower limit of the funnel $(2 \mathrm{~cm})$, a known diameter (d) of the round platform remained positioned in order of receiving the powder that was flowing through the funnel. The height $(h)$ was measured, and the angle of repose $\left(a^{\circ}\right)$ was calculated by the following equations:

$\alpha=$ Arco-tag $h / 0.5 \mathrm{~d}$

$$
\text { Tang } \alpha=\mathrm{h} / 0.5 \mathrm{~d}
$$

\section{Artepillin C content and chromatographic profile}

Analyses were conducted using a Shimadzu (Kyoto, Japan) HPLC equipped with a CBM-20A controller, a LC-20AT quaternary pump, a SPD-M 20A diode-array detector, and Shimadzu LC solution software, version 1.21 SP1. A Shimadzu Shim-Pack CLC-ODS column $(4.6 \mathrm{~mm} \times 250 \mathrm{~mm}$, particle diameter of $5 \mu \mathrm{m}$, pore diameter of $100 \AA$ ) was used. The mobile phase consisted of methanol (B), and of a solution of water-formic acid $(0.1 \%$ $\mathrm{v} / \mathrm{v}), \mathrm{pH} 2.7(\mathrm{~A})$. The method consisted of a linear gradient of $20-95 \%$ of $B$ over a period of $77 \mathrm{~min}$ at a flow rate of $0.8 \mathrm{~mL} /$ $\mathrm{min}$. The injection volume was $10 \mu \mathrm{l}$. The column oven temperature was set at $40^{\circ} \mathrm{C}$. Detection was set at $275 \mathrm{~nm}[11,26]$.
Working solutions were prepared daily in methanol in the following concentration ranges: artepillin C 10.06-160.96 $\mu \mathrm{g} /$ $\mathrm{mL}$, caffeic acid 1.06-16.96 $\mu \mathrm{g} / \mathrm{mL}$; $p$-coumaric acid 5.04-80.64 $\mu \mathrm{g} / \mathrm{mL}$; cinnamic acid $0.40-6.40 \mu \mathrm{g} / \mathrm{mL}$ and aromaden-drin4'-O-methyl ether $2.0-32.0 \mu \mathrm{g} / \mathrm{mL}$.

The samples of propolis dry extracts were weighed $(30 \mathrm{mg}$ ) on an analytical balance and transferred into $10 \mathrm{~mL}$ volumetric flasks and added with $5.0 \mathrm{~mL}$ of HPLC grade methanol. Then, each flask was kept in ultrasound for 10 minutes, and then the volume was completed with MilliQ acidified water. The samples were filtered through a $0.45 \mu \mathrm{m}$ filter before analyses.

\section{Particle morphology by SEM}

Scanning electron microscopic (SEM) images were obtained with a Field emission scanning electron microscope (FESEM, JEOL JSM-7500F). Samples were sprayed on aluminum stubs with colloidal carbon and coated with gold in a Balzers SCD 050 sputter coater.

\section{Antibacterial assay}

To evaluate the antibacterial activity of the powders, the broth macrodilution method recommended by the Clinical and Laboratory Standards Institute [33] was used, with some modifications. In this study, the following microorganisms were used: Staphylococcus aureus ATCC 25923 and Escherichia coli ATCC 25922. Propolis was assessed from 0.24 to $125 \mathrm{mg} /$ $\mathrm{mL}$ final concentration.

Due to the turbidity of the test broth when the powders were diluted in the culture medium, it was not possible to determine the minimum inhibitory concentration (MIC). Therefore, the antibacterial activity of the samples was assessed by means of the minimum bactericidal concentration (MBC), which was determined by subculturing $20 \mu \mathrm{L}$ aliquots from each sample in the broth dilution series onto agar plates (Mueller Hinton agar). The plates were incubated at $35^{\circ} \mathrm{C}$ aerobically for $24 \mathrm{~h}$. After the incubation period, the MBC was determined. $M B C$ was defined as the lowest concentration of the extract required to kill all the individual microorganisms being tested.

\section{Results}

\section{Physicochemical characterization}

Among the characterization parameters, the criteria for selecting the encapsulating system were density, flavonoid content and mainly the yielding of propolis extract powder obtained. Our preliminary studies employing different excipient ratios presented Apparent Density (D) in the range of 0.252-0.555 $(\mathrm{g} / \mathrm{mL})$, Flavonoid Content $(\mathrm{FC})$ in the range of 10.77-33.77 $\mathrm{mg} / \mathrm{g}$ and Yield $(\mathrm{Y})$ in the range of $28.44-77.51 \%$. Therefore, based on these results, the best encapsulating systems chosen were: (A) arabic gum and silicon dioxide (1:1) and (B) modified starch and silicon dioxide (1:1). Next, a factorial planning was conducted for these encapsulating systems.

According to the Box-Behnken Planning, 15 different drying conditions were proposed, resulting in 15 different dried 
extracts for each encapsulating system chosen. These samples were assessed regarding their physicochemical and chemical profile for a thorough evaluation of quality interactions during spray drying. Additionally, microparticle morphology and the biological properties of these encapsulating systems at the best drying conditions were assessed as further described. The results of the physicochemical characterization of spraydried extracts, employing encapsulating systems $A$ and $B$ are shown in Tables 2 and 3, respectively.

Statistica version 7, statistical analysis (ANOVA) and analysis of response surface software were employed for the assessed parameters. Regarding the propolis content, flavonoid content, moisture and angle of repose parameters, all variables of the drying process for encapsulating system A did not influence the dry extracts, significantly. Statistical analysis indicated the existence of variables effects on the drying process parameters, but with low importance. The variance of the factors studied with the error of the experiment was not significant.

Regarding the yielding, Carr index and Hausner factor parameters for the encapsulating system $B$, it was observed that all variables of the drying process did not influence the dry extracts, significantly. Table 4 shows the complete summary of the ANOVA test and shows that the effects of temperature $(\mathrm{T})$, extract feed rate (ExtrFR) and air flow rate (AirFR), as well as, their squared forms, presented significant levels. In this work, the minimum significance level of $5 \%$ was adopted for all variables studied.

For the spray drying encapsulating system $A$, the vari- ables of the drying process influenced significantly the dry extracts regarding: Density, Yield, Carr index and Hausner factor. For this formulation, it was observed that to obtain the bulk Density values near the optimum value, $0.380 \mathrm{~g} / \mathrm{mL}$, the optimum drying conditions are: temperatures around $80^{\circ} \mathrm{C}$ with air flow rate in the system at $3.2 \mathrm{~m}^{3} / \mathrm{min}$ (Figure 1a). To obtain the highest yielding (Figure 1 $\mathbf{b}$ ), the best conditions involved temperatures around $105^{\circ} \mathrm{C}$ with the extract feed rate of $5 \mathrm{~mL} / \mathrm{min}$ and air flow rate of $3.2 \mathrm{~m}^{3} / \mathrm{min}$. It was observed that the higher the temperature and the air flow rate, the higher the dry propolis extract yield was. Statistical analysis for these parameters demonstrated that almost all parameters influenced the drying process in the product, and among all factor, the temperature and its square affected it at the highest level. It is demonstrated that for good flowability, the powder must present Carr index below 15 [30], Hausner factor below 1.25 [31]. By analyzing the data, the Carr index and the Hausner factor presented smaller values when the temperature is around $55^{\circ} \mathrm{C}$ with an extract feed rate at $5 \mathrm{~mL} /$ min, or at a temperature of $105^{\circ} \mathrm{C}$ with an extract feed rate at $13 \mathrm{~mL} / \mathrm{min}$. In both cases, the air flow rate should be set at 2.5 $\mathrm{m}^{3} / \mathrm{min}$. Accordingly to these conditions, dry extracts with Carr index of about 20.0 and Hausner factor of 1.20 can be reached. For the spray drying encapsulating system $B$, the variables of the drying process influenced significantly the dry extracts regarding propolis content, flavonoid content, density, moisture and angle of repose (Figures 2 and $\mathbf{3}$ ). For this formulation, propolis content was influenced by the quadratic term

Table 2. Physicochemichal characterization of the samples obtained according to the Box-Behnken Planning for encapsulating agent comprising arabic gum and silicon dioxide (1:1) (system A).

\begin{tabular}{|c|c|c|c|c|c|c|c|c|}
\hline \multirow{2}{*}{$\begin{array}{l}\text { Encapsulating } \\
\text { System A }\end{array}$} & \multirow{2}{*}{$\begin{array}{l}\mathrm{PC}^{*} \\
(\mathrm{mg} / \mathrm{g})\end{array}$} & \multirow{2}{*}{$\begin{array}{l}\mathrm{FC}^{\dagger} \\
(\mathrm{mg} / \mathrm{g})\end{array}$} & \multirow{2}{*}{$\begin{array}{l}D^{\ddagger} \\
(\mathrm{g} / \mathrm{ml})\end{array}$} & \multirow{2}{*}{$\begin{array}{l}\text { Moisture } \\
(\% \text { w/w })\end{array}$} & \multirow{2}{*}{$\begin{array}{l}\text { Yield } \\
(\% \mathrm{~m} / \mathrm{m})\end{array}$} & \multicolumn{3}{|c|}{ Flow characteristics } \\
\hline & & & & & & Carr index & Hausner factor & $\alpha^{\circ} \$$ \\
\hline 1 & 45.206 & 26.679 & 0.312 & 3.345 & 57.10 & 26.316 & 1.263 & 37.90 \\
\hline 2 & 40.907 & 25.629 & 0.279 & 2.462 & 56.43 & 35.897 & 1.359 & 32.09 \\
\hline 3 & 49.992 & 25.204 & 0.342 & 3.567 & 59.48 & 42.857 & 1.429 & 44.22 \\
\hline 4 & 48.934 & 25.712 & 0.338 & 2.808 & 64.07 & 51.515 & 1.515 & 43.90 \\
\hline 5 & 49.417 & 23.247 & 0.357 & 4.634 & 54.50 & 62.857 & 1.629 & 42.58 \\
\hline 6 & 42.546 & 24.822 & 0.313 & 3.835 & 31.85 & 61.290 & 1.613 & 24.93 \\
\hline 7 & 44.280 & 25.900 & 0.336 & 3.465 & 59.09 & 57.576 & 1.576 & 40.50 \\
\hline 8 & 41.961 & 25.217 & 0.299 & 2.235 & 67.60 & 48.571 & 1.486 & 36.72 \\
\hline 9 & 44.410 & 25.886 & 0.389 & 3.268 & 41.32 & 51.515 & 1.515 & 42.58 \\
\hline 10 & 42.572 & 25.789 & 0.310 & 2.972 & 56.30 & 70.000 & 1.700 & 39.04 \\
\hline 11 & 44.184 & 26.263 & 0.406 & 2.892 & 62.28 & 62.500 & 1.625 & 40.86 \\
\hline 12 & 42.320 & 26.434 & 0.384 & 3.227 & 59.65 & 67.742 & 1.677 & 40.86 \\
\hline 13 & 43.311 & 26.037 & 0.360 & 2.263 & 62.41 & 62.500 & 1.625 & 39.41 \\
\hline 14 & 46.053 & 26.292 & 0.399 & 3.875 & 62.54 & 60.606 & 1.606 & 36.72 \\
\hline 15 & 44.998 & 26.070 & 0.351 & 2.525 & 62.91 & 64.516 & 1.645 & 42.90 \\
\hline
\end{tabular}

*PC: Propolis content; ${ }^{\dagger} \mathrm{FC}$ : Flavonoid content; ${ }^{\star} \mathrm{D}$ : Bulky density; ${ }^{\circledR} \alpha^{0}$ : Angle of repose 
Table 3. Physicochemichal characterization of the samples obtained according to the Box-Behnken Planning for encapsulating agent comprising modified starch and silicon dioxide (1:1) (system B).

\begin{tabular}{|c|c|c|c|c|c|c|c|c|}
\hline \multirow{2}{*}{$\begin{array}{l}\text { Encapsulating } \\
\text { System B }\end{array}$} & \multirow{2}{*}{$\begin{array}{l}C^{*} \\
(\mathrm{mg} / \mathrm{g})\end{array}$} & \multirow{2}{*}{$\begin{array}{l}\mathrm{FC}^{\dagger} \\
(\mathrm{mg} / \mathrm{g})\end{array}$} & \multirow{2}{*}{$\begin{array}{l}D^{\ddagger} \\
(g / m l)\end{array}$} & \multirow{2}{*}{$\begin{array}{l}\text { Moisture } \\
(\% \mathrm{w} / \mathrm{w})\end{array}$} & \multirow{2}{*}{$\begin{array}{l}\text { Yield } \\
(\% \mathrm{~m} / \mathrm{m})\end{array}$} & \multicolumn{3}{|c|}{ Flow Characteristics } \\
\hline & & & & & & Carr index & Hausner factor & $\alpha^{\circ} \$$ \\
\hline 1 & 47.617 & 25.376 & 0.497 & 3.210 & 77.86 & 47.059 & 1.471 & 37.442 \\
\hline 2 & 47.598 & 25.977 & 0.476 & 2.448 & 69.48 & 45.714 & 1.457 & 43.488 \\
\hline 3 & 50.740 & 25.876 & 0.496 & 3.519 & 75.64 & 44.444 & 1.444 & 41.715 \\
\hline 4 & 46.885 & 24.752 & 0.431 & 2.827 & 65.64 & 45.714 & 1.457 & 26.696 \\
\hline 5 & 47.186 & 24.883 & 0.550 & 4.121 & 61.72 & 85.714 & 1.857 & 32.619 \\
\hline 6 & 47.285 & 25.605 & 0.507 & 2.327 & 45.06 & 65.625 & 1.656 & 29.249 \\
\hline 7 & 45.348 & 24.558 & 0.562 & 2.892 & 76.97 & 60.606 & 1.606 & 31.204 \\
\hline 8 & 48.326 & 26.116 & 0.469 & 2.853 & 61.50 & 51.429 & 1.514 & 39.838 \\
\hline 9 & 45.388 & 25.666 & 0.504 & 3.621 & 58.91 & 70.000 & 1.700 & 42.791 \\
\hline 10 & 47.563 & 27.899 & 0.509 & 3.999 & 60.70 & 57.576 & 1.576 & 39.450 \\
\hline 11 & 43.539 & 28.733 & 0.496 & 4.268 & 68.06 & 40.541 & 1.405 & 39.060 \\
\hline 12 & 42.693 & 28.560 & 0.474 & 4.176 & 67.68 & 47.059 & 1.471 & 39.450 \\
\hline 13 & 47.541 & 27.444 & 0.497 & 4.004 & 62.40 & 54.545 & 1.545 & 30.720 \\
\hline 14 & 49.006 & 27.367 & 0.479 & 3.840 & 61.71 & 47.059 & 1.471 & 33.540 \\
\hline 15 & 45.336 & 27.047 & 0.517 & 3.385 & 68.78 & 59.375 & 1.594 & 35.750 \\
\hline
\end{tabular}

${ }^{*}$ PC: Propolis content; ${ }^{\dagger} \mathrm{FC}$ : Flavonoid content; ${ }^{\ddagger} \mathrm{D}$ : Bulky density; ${ }^{\varsigma} \alpha^{0}$ : Angle of repose

Table 4. Summary of significance levels for all factor and dependent variables studied.

\begin{tabular}{|c|c|c|c|c|c|c|c|c|c|c|c|c|c|c|c|c|}
\hline \multirow{3}{*}{$\begin{array}{l}\text { Parameter } \\
\text { Sample }\end{array}$} & \multirow{2}{*}{\multicolumn{2}{|c|}{$\mathrm{PC}^{\star} \%$}} & \multirow{2}{*}{\multicolumn{2}{|c|}{$\mathrm{FC} \dagger \%$}} & \multirow{2}{*}{\multicolumn{2}{|c|}{$\mathrm{D} \neq \%$}} & \multirow{2}{*}{\multicolumn{2}{|c|}{ Moisture \% }} & \multirow{2}{*}{\multicolumn{2}{|c|}{ Yield \% }} & \multicolumn{6}{|c|}{ Flow characteristics } \\
\hline & & & & & & & & & & & \multicolumn{2}{|c|}{ Carr index \% } & \multicolumn{4}{|c|}{ Hausner factor $\% \alpha^{\circ} \oint \%$} \\
\hline & $\mathbf{A}$ & B & $\mathbf{A}$ & B & A & B & A & B & A & B & A & B & A & B & A & B \\
\hline $\mathrm{T} \|$ & $\mathrm{NS}^{\dagger \dagger}$ & NS & NS & NS & NS & 0.010 & NS & 0.016 & NS & NS & 0.015 & NS & 0.015 & NS & NS & NS \\
\hline $\mathrm{T}^{2}$ & NS & 0.021 & NS & 0.007 & 0.033 & NS & NS & NS & NS & NS & 0.000 & NS & 0.000 & NS & NS & NS \\
\hline ExtrFRg & NS & NS & NS & NS & NS & NS & NS & NS & NS & NS & 0.001 & NS & 0.001 & NS & NS & NS \\
\hline ExtrFR $^{2}$ & NS & NS & NS & NS & NS & 0.048 & NS & NS & NS & NS & 0.011 & NS & 0.011 & NS & NS & 0.034 \\
\hline $\operatorname{AirFR}^{\star *}$ & NS & 0.033 & NS & NS & NS & NS & NS & NS & 0.004 & NS & NS & NS & NS & NS & NS & NS \\
\hline $\mathrm{AirFR}^{2}$ & NS & NS & NS & NS & NS & NS & NS & NS & 0.023 & NS & 0.008 & NS & 0.008 & NS & NS & NS \\
\hline $\mathrm{T}^{*}$ ExtrFR & NS & NS & NS & NS & NS & NS & NS & NS & NS & NS & NS & NS & NS & NS & NS & 0.005 \\
\hline $\mathrm{T}^{*}$ AirFR & NS & NS & NS & NS & NS & NS & NS & NS & 0.034 & NS & 0.003 & NS & 0.003 & NS & NS & 0.010 \\
\hline ExtrFR $^{*}$ AirFR & NS & NS & NS & NS & NS & NS & NS & NS & NS & NS & NS & NS & NS & NS & NS & NS \\
\hline
\end{tabular}

${ }^{*} \mathrm{PC}$ : propolis content; ${ }^{\dagger} \mathrm{FC}$ : flavonoid content; ${ }^{\star} \mathrm{D}$ : bulky density; ${ }^{\varsigma \alpha^{\circ}}$ : angle of repose; "T: temperature; ${ }^{\circ}$ ExtrFR: extract feed rate

${ }^{*}$ AirFR: air flow rate; ${ }^{\dagger \dagger} \mathrm{NS}$ : not significant

of temperature (nonlinear effect), with $2.1 \%$ of significance. This parameter was also influenced by the air flow rate with a linear effect at $3.3 \%$ of significance. In order to reach the theoretical propolis content, i.e., around $50 \%$ by weight of propolis, it could be suggested that the best drying conditions would be temperatures around $105^{\circ} \mathrm{C}$ or $55^{\circ} \mathrm{C}$ with an extract feed rate between 9 and $10 \mathrm{~mL} / \mathrm{min}$, with an air flow rate of $3.2 \mathrm{~m}^{3} / \mathrm{min}$ (Figure 3a). This condition corroborates with the ideal conditions for achieving the desired density at $55^{\circ} \mathrm{C}$. The flavonoid content was influenced by the quadratic term of temperature (nonlinear effect), with $0.7 \%$ of significance. The best drying conditions regarding flavonoid content would be temperatures around $80^{\circ} \mathrm{C}$ with an extract feed rate of 5 $\mathrm{mL} / \mathrm{min}$ and air flow rate of $3.2 \mathrm{~m}^{3} / \mathrm{min}$ or extract feed rate of $13 \mathrm{~mL} / \mathrm{min}$ with air flow rate at $1.8 \mathrm{~m}^{3} / \mathrm{min}$ system (Figure 2 ). Density was influenced by the temperature with a linear effect at $1.0 \%$ of significance (Figure $3 \mathbf{b}$ ). The extract feed rate and its square influenced density as well, at $4.8 \%$ of significance. Moisture was influenced by temperature (nonlinear effect), with $1.6 \%$ of significance. With respect to dry extract moisture, it was observed that the best drying conditions occurred at temperatures around $105^{\circ} \mathrm{C}$, with extract feed rate between 
(a)

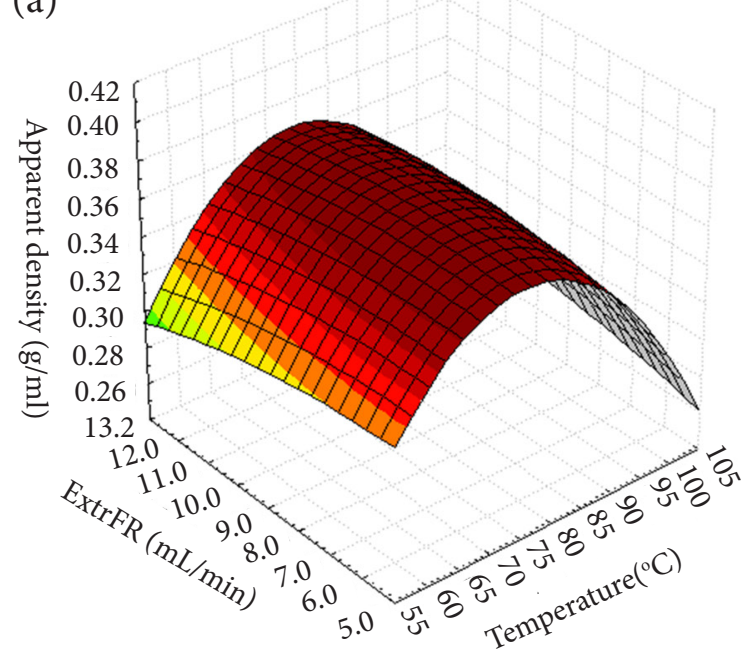

(b)

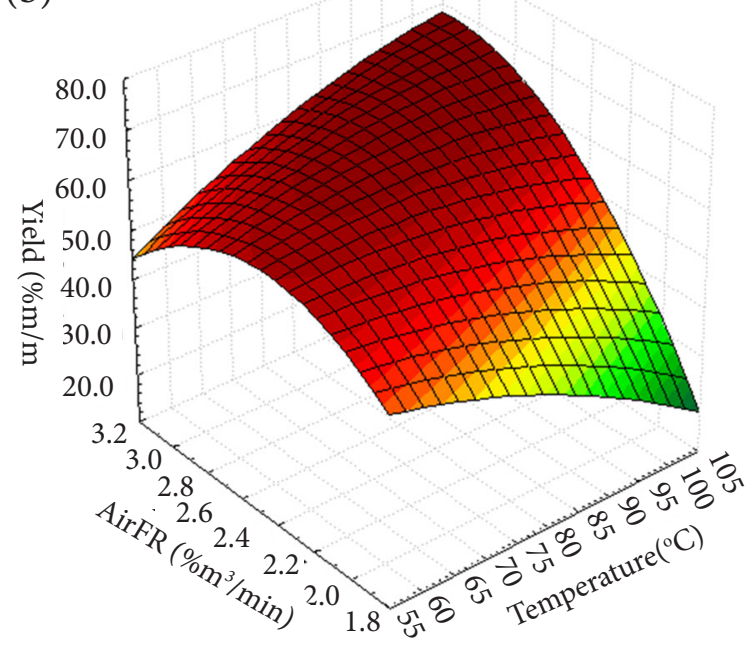

Figure 1. Graphical presentation of the response surface of the apparent density (a) and yielding (b) as a function of temperature and extract feed rate (ExtrFR) (a) and air flow rate (AirFR) (b) for sample A (encapsulating system A; arabic gum and silicon dioxide, 1:1).

(a)

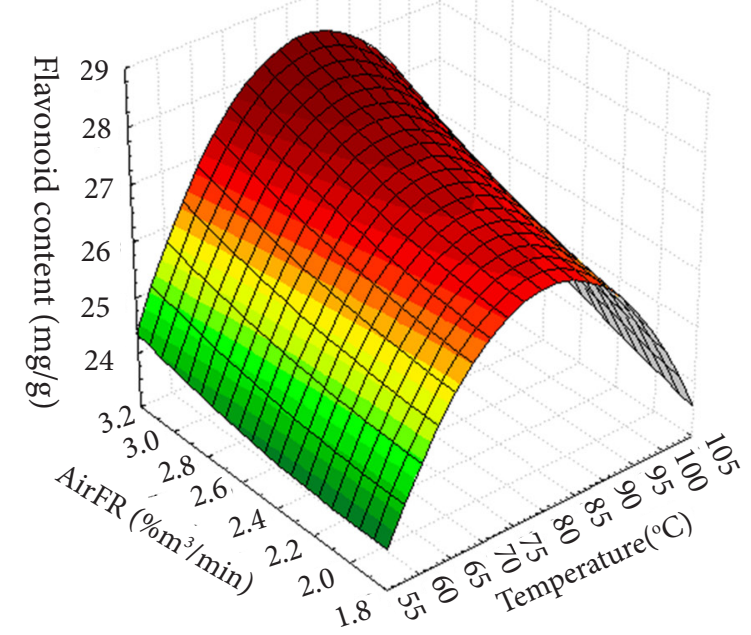

(b)

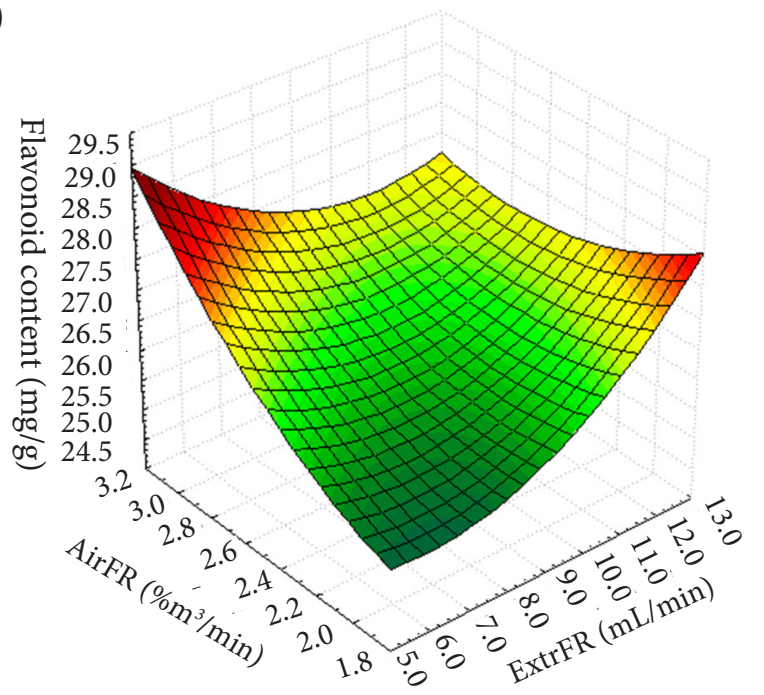

Figure 2. Graphical presentation of the response surface of Flavonoid Content as a function of Air Flow Rate and

Temperature (a) or Extract Feed Rate (b) for sample B (encapsulating system B; modified starch and silicon dioxide, 1:1).

5 and $13.0 \mathrm{~mL} / \mathrm{min}$ for the air flow of $1.8 \mathrm{~m}^{3} / \mathrm{min}$ (Figure 3c). In relation to the angle of repose, it was influenced by the quadratic term of the extract feed rate with $3.4 \%$ significance level (nonlinear effect). In addition, the angle of repose was also sensitive to the effect of the interaction between the extract feed rate and the temperature $(0.55 \%$ significance) and the interaction between the extract feed rate and the air flow rate, which promoted an effect at $1.0 \%$ of significance level. For the good flowability of the dry extract, the angle of repose should be between 20 and $30^{\circ}$ [31]. Thus, analyzing the obtained data, it could be suggested that the best drying conditions would be temperatures around $100^{\circ} \mathrm{C}$, with extract feed rate of $11.5 \mathrm{~mL} / \mathrm{min}$ with an air flow rate of approximately $1.8 \mathrm{~m}^{3} / \mathrm{min}$.

\section{Artepillin C content and chemical profile}

Quantitative chemical characterization for both encapsulating systems ( $A$ and $B$ ) are listed in Table 5 . The quantitative range 
for each chemical compound, as well as, its percentage in relation to the theoretical value can be observed.

Statistical analysis demonstrated the influence of the process parameters in the $p$-coumaric acid, cinnamic acid and artepellin $\mathrm{C}$ markers amount for the encapsulating system A (data not shown). It was observed that both $p$-coumaric acid and cinnamic acid were sensitive to quadratic term of temperature with a nonlinear effect and with significance levels at $4.1 \%$ and $3.4 \%$, respectively. In relation to artepillin C content, it was observed influence by the interaction between the temperature and the air flow system, a linear effect, with $2.4 \%$ of significance (Figure 4 ). On the other hand, statistical analysis showed no significant effect of the process parameters in the other compounds of the encapsulating system B.

Although only a few process parameters were statistically influenced, it does not mean that other variables did not exert effect on the process, but that the variance of the factors studied with the error of the experiment was not significant, thus suggesting that the effects of these variables are not important to the process.
Analysis of Figure $4 a$, allowed to suggest that the best drying conditions considering $p$-coumaric acid would be: temperature between $65^{\circ} \mathrm{C}$ and $75^{\circ} \mathrm{C}$, extract feed rate from 12.75 to $13.0 \mathrm{~mL} / \mathrm{min}$, with air flow rate from the system between 3.0 and $3.2 \mathrm{~mL} / \mathrm{min}$. At this condition, the propolis dry extract would present $p$-coumaric acid at $6.70 \mathrm{mg} / \mathrm{g}$, close to ideal amount (Figure 4a).

By considering cinnamic acid, the temperature would be set between $75^{\circ} \mathrm{C}$ and $85^{\circ} \mathrm{C}$ with extract feed rate between $10.0 \mathrm{~mL} / \mathrm{min}$ and $11.0 \mathrm{~mL} / \mathrm{min}$, with air flow rate between 2.4 $\mathrm{m}^{3} / \mathrm{min}$ and $2.6 \mathrm{~m}^{3} / \mathrm{min}$. At this condition, the propolis dry extract would present cinnamic acid at $0.690 \mathrm{mg} / \mathrm{g}$, close to the ideal amount (Figure 4b).

Regarding artepillin C, the temperature would be set at $105^{\circ} \mathrm{C}$ with extract feed rate at $5.0 \mathrm{~mL} / \mathrm{min}$ or temperature set at $55^{\circ} \mathrm{C}$ with extract feed rate at $13.0 \mathrm{~mL} / \mathrm{min}$. In both situations, air flow rate between $1.8 \mathrm{~m}^{3} / \mathrm{min}$ and $3.2 \mathrm{~m}^{3} / \mathrm{min}$. At this condition, the propolis dry extract would present artepillin C at $33.0 \mathrm{mg} / \mathrm{g}$ close to the ideal amount considering $100 \%$ of dryness efficiency (Figure 4c), i.e., around 100\% of recovery of this compound.

\section{(a)}

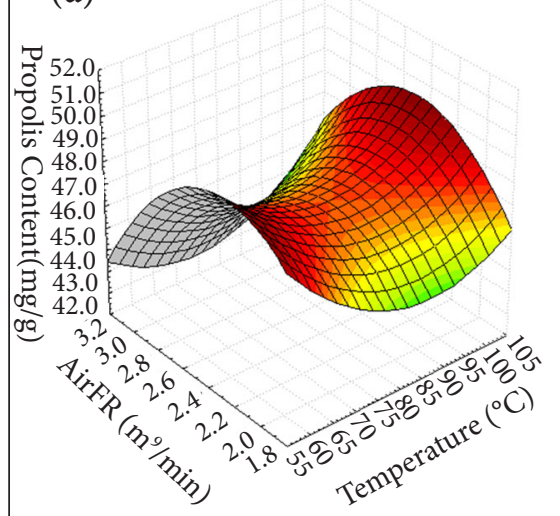

(b)

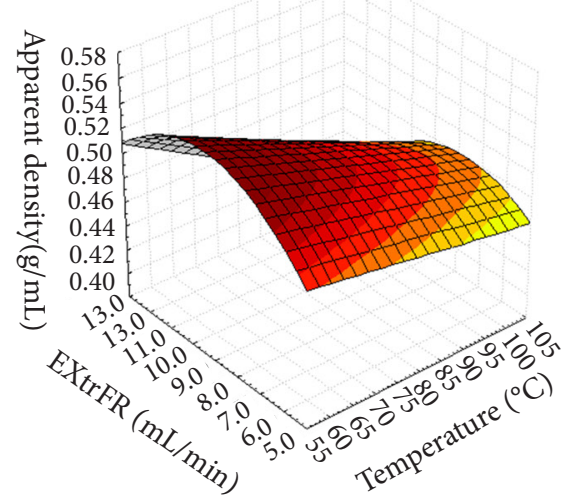

(c)

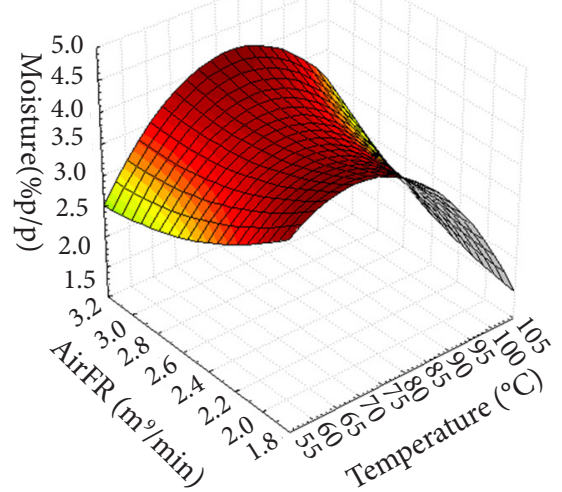

Figure 3. Graphical presentation of the response surface of: (a) Propolis Content as a function of Air Flow Rate and Temperature; (b). Bulky Density as a function of the Extract Feed Rate and Temperature; and (c) Moisture as a function of the Air Flow Rate and apparent density for sample B (encapsulating system B; modified starch and silicon dioxide, 1:1).

Table 5. Quantitative range of the chemical markers found in the dry propolis extract obtained for the encapsulating systems A (arabic gum and silicon dioxide, 1:1) and B (modified starch and silicon dioxide, 1:1). Additionally, the percentage in relation of the theoretical value of the markers is presented.

\begin{tabular}{lllll}
\hline Chemical compound & \multicolumn{2}{l}{$\begin{array}{l}\text { Encapsulating system A } \\
\text { (lowest and highest amount) }\end{array}$} & \multicolumn{2}{l}{$\begin{array}{l}\text { Encapsulating system B } \\
\text { (lowest and highest amount) }\end{array}$} \\
& (mg/g) & \% TV $^{*}$ & (mg/g) & \% TV \\
\hline Caffeic acid & $1.250 / 1.440$ & $92.940 / 107.060$ & $1.190 / 1.500$ & $88.480 / 111.520$ \\
p-coumaric acid & $6.090 / 6.630$ & $91.210 / 99.300$ & $5.690 / 7.330$ & $85.220 / 109.780$ \\
Cinnamic acid & $0.620 / 0.710$ & $92.810 / 106.290$ & $0.700 / 0.860$ & $104.800 / 128.740$ \\
Aromadendrin & $4.190 / 4.460$ & $110.520 / 117.650$ & $4.030 / 5.180$ & $106.300 / 136.640$ \\
Isosakuranetin & $10.100 / 11.270$ & $92.490 / 103.210$ & $9.140 / 11.910$ & $83.700 / 109.070$ \\
Artepillin C & $28.440 / 33.290$ & $99.960 / 117.001$ & $27.040 / 34.820$ & $95.040 / 122.390$ \\
\hline
\end{tabular}

$\star \%$ of the theoretical value 

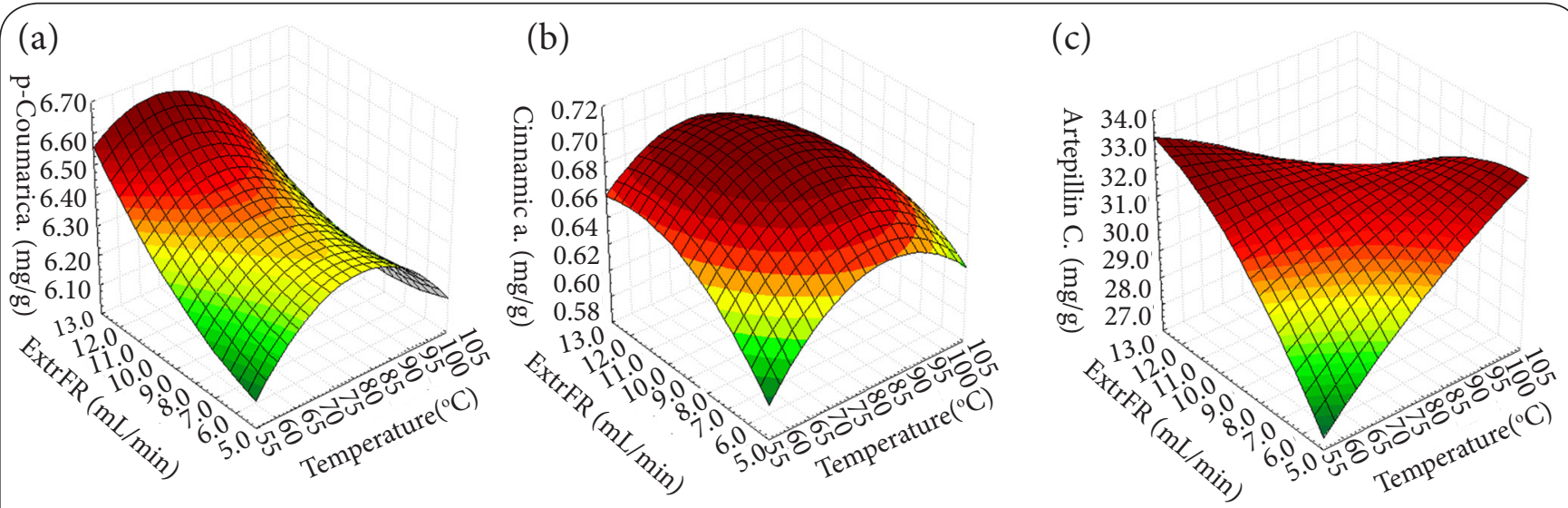

Figure 4. Graphical presentation of the response surface for the chemical markers in the spray-dried propolis powders (a) p-coumaric acid, (b) cinnamic acid and (c) artepillin $\mathrm{C}$ as a function of extract feed rate and temperature for sample $\mathrm{A}$ (encapsulating system A; arabic gum and silicon dioxide, 1:1).

\section{Particle morphology}

Both encapsulatings studied furnished particles with an agglomerate type of rounded shape with rough surface. The particles may have vacuole in its core and holes in the surface. The microparticles obtained from formulation $B$ showed higher porosity than those obtained from the composition A (Figures 5 and 6). In general, nanoparticles presented diameter among 1 and $5 \mu \mathrm{m}$. Spray-dried propolis using arabic gum and octenyl succinic anhydride (OSA) starch as carriers produced round particles with sizes ranging from 15 to $24 \mu \mathrm{m}$ [24].

\section{Antibacterial assay}

The minimum bactericidal concentrations (MBC) of the encapsulating systems $A$ and $B$ showed that the samples were effective against $S$. aureus, whereas $E$. coli was resistant to them. There was no significant difference between systems A and B ( $p>0.05)$, (Table 6).

\section{Discussion}

The ultimate goal of this work was to develop a propolis extract with a high content of propolis and especially with high artepillin C content. Thus, the 1:1 propolis:excipient ratio was set. Initially, the procedure of sample preparation and the drying conditions were set to compare the parameters used in the extract characterization, yielding, total flavonoid content and bulk density, which were also analyzed in the developed formulations employing arabic gum, modified starch and silicon dioxide at different ratios.

Arabic gum (or acacia) comprises a highly branched galactose, arabinose, rhamnose and glucuronic acid arrangement still containing about $2 \%$ of a protein component covalently bonded to the molecules of this arrangement, exerting an important role in determining the emulsifying properties of the gum. It is historically considered as the encapsulating material par excellence thanks to its solubility, low viscosity, good emulsifying properties, mild flavor and high oxidative
Table 6. Minimum bactericidal concentration (MBC) of propolis dry extracts obtained for the encapsulating system $A$ (arabic gum and silicon dioxide, 1:1) and B (modified starch and silicon dioxide, 1:1) against Staphylococcus aureus and Escherichia coli.

\begin{tabular}{l|ll}
\hline Microorganism & \multicolumn{2}{|c}{ MBC $(\mathbf{m g} / \mathbf{m l})$} \\
\cline { 2 - 3 } & $\begin{array}{l}\text { Encapsulating } \\
\text { system A }\end{array}$ & $\begin{array}{l}\text { Encapsulating } \\
\text { system B }\end{array}$ \\
\hline S.aureus ATCC 25923 & $3.90 \pm 0.00$ & $1.95 \pm 0.00$ \\
E. coli ATCC 25922 & $31.25 \pm 0.00$ & $31.25 \pm 0.00$ \\
\hline
\end{tabular}

Data are shown as mean \pm SD $(n=3)$

stability conferred to oils, by forming a protective film. On the other hand, there are problems of high cost and availability. Therefore, the search for partial or total replacement has been encouraged [34].

Starch may be chemically modified through partial hydrolysis followed by reaction with a hydrophobic component. Thus, starch is attracted to the oil-water interface of an emulsion and can, therefore, be used as encapsulating. A compound commonly used for binding the starch is octenyl-succinate. The polymer thus produced (Capsul ) presents good water solubility and excellent retention of the volatile flavor material after drying also to be applied as the main replacement for arabic gum [35].

The temperature influence on the yielding and powder flowability has been reported elsewhere. Experimental data have shown increased drying temperatures significantly increased the dry powder yield of extracts from the Monascus ruber van Tiegham fermentation broth. Additionally, improvement in powder flow properties was also observed, which may be related to lower moisture contents [36].

Additionally, demonstrating the flavonoid yield observed in other reported works is also relevant. Marquele et al., [21] have shown recoveries of the flavonoid content in the dry propolis extract, obtained by spray drying, in the 30.6 to $40.8 \%$ range. While, in the present study, the encapsulating system employing arabic gum promoted a recovery in the 

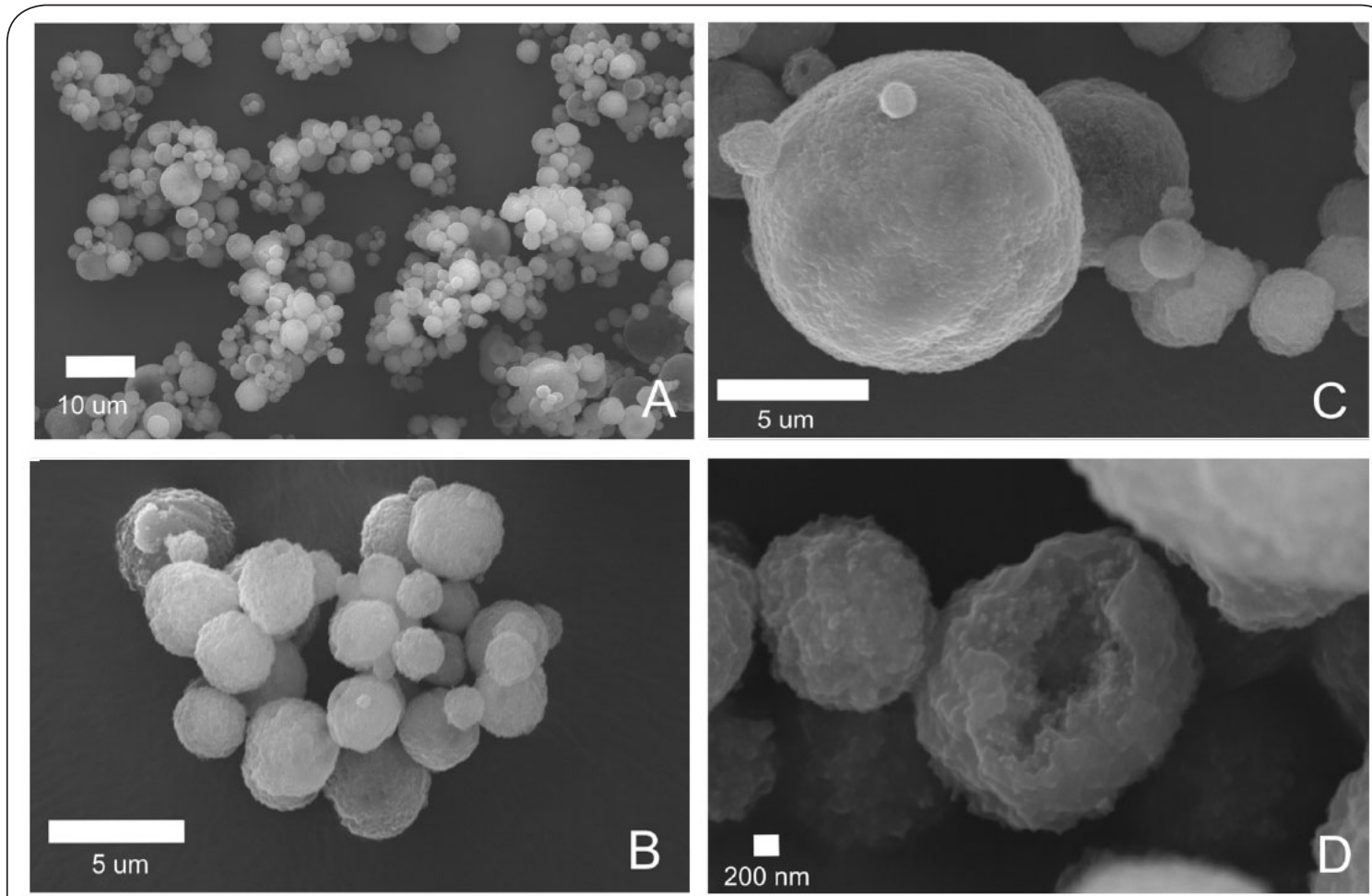

Figure 5. Representative electron micrographs of encapsulating system A. A: Distribution of microparticles from the sample, showing the agglomerated type. B: In particular, a typical agglomerate containing microparticles of approx. $2 \mathrm{~mm}$ in diameter. C: In particular, a spherical microparticle surface roughness of approx. $8 \mu \mathrm{m}$ in diameter near microparticles approx. $1 \mu \mathrm{m}$ in diameter. D. A spherical nanoparticle with a rough surface, cracked, showing that it has a central vacuole. Scales bars: A: $10 \mu \mathrm{m}, \mathbf{B}$ and C: $5 \mu \mathrm{m}$, D: $200 \mathrm{~nm}$.

range of $93.78 \%$ to $107.62 \%$, and for the samples containing modified starch it reached $99.06 \%$ and $115.91 \%$. Therefore, the encapsulating systems employed in this proposal were superior in terms of recovery of flavonoid content. Bruschi et al., [27] obtained in the drying process of propolis with encapsulating system based on gelatin, yields ranging from $28.46 \%$ to $51.48 \%$. In our work we obtained yields of approximately $70 \%$, allowing to infer that the encapsulating systems used in this work were better in this regard, as well.

Considering the quantitative chemical characterization, both encapsulating systems presented chemical compound losses, but minimized losses when compared with other reports. Souza et al., [26], in a study conducted to obtain dry green propolis with a non-informed encapsulating system, have reported that all studied chemical markers suffered degradation during the process, ranging from 30 and $50 \%$. In the present study, we observed that the chemical markers degradation depended on the employed encapsulating system. For the encapsulating system $A$, the losses were from $0.04 \%$ (artepillin $C$ ) to $8.79 \%$ (p-coumaric acid). For the encapsulating system B, the decrease was $0.94 \%$ for artepillin $C$ and $16.30 \%$ for isosakuranetin, considering the samples with the lowest contents. Thus, although a direct comparison among the different studies is not possible, due to the lack of composition information, the present work evidences superiority regarding the markers stability.

Trubiano and Lacourse [37] demonstrated that the octenylsuccinate modified starch, promoted the reduction of flavor compounds about 20 times lower than with arabic gum (encapsulating system A). The results in the present work for the chemical markers of the standardized propolis extract showed that this protection was not observed in such proportion. However, in a broader parameter, i.e., the flavonoid content, modified starch gave a higher dry matter recovery (99.06\%) compared to the arabic gum system (93.78\%). On the other hand, the starches offer little protection from oxidation during storage, furthermore, modified starches with high dextrose equivalent values, decrease the glass transition temperature, increasing the agglomeration (caking) of the obtained powder [34]. Thus, one should evaluate the cost-benefit for selecting the most appropriate system for encapsulating the desired application.

Aerosil 200, the polymer consisting of silicon dioxide (SiO2), visually identified as a slight bluish white powder technology, is a highly used material to decrease the adhesiveness of the microparticle formed in the drying chamber of the spray dryer. This technology leads to increased recoveries during the drying process, an important feature observed in the present study. In some cases, it also increases the absorption and micro- 


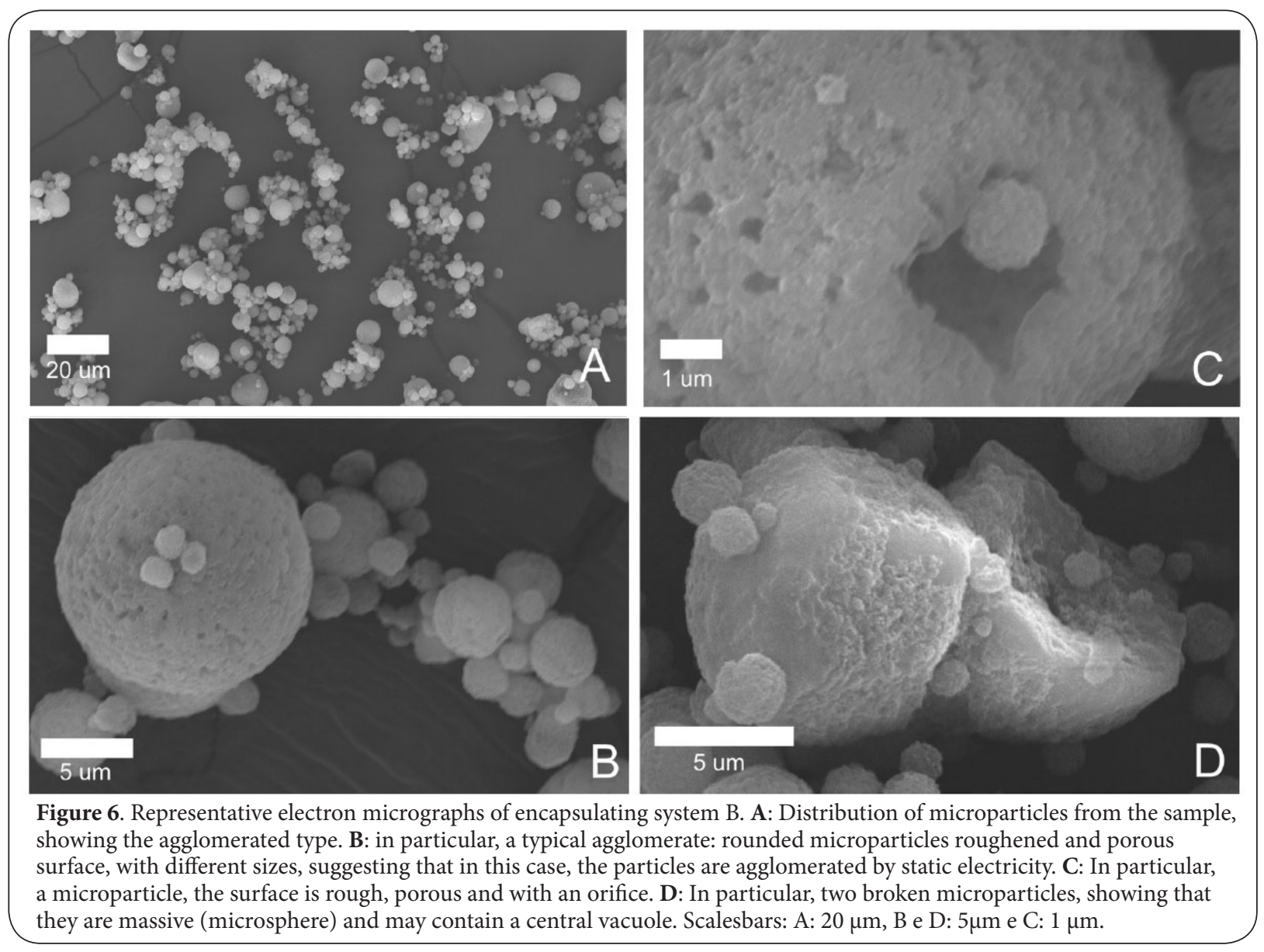

encapsulation of the material, decreasing the particle size, enhancing drying efficiency, and the flowability of the final product [38]. Low concentrations of silicon dioxide are suitable to adjust the rheological properties. Working as thickening agent, it forms a thick temporary three dimensional crystal structure, macroscopically visible, which under mechanical stress becomes fluid. It also prevents or delays sedimentation, mainly due to the thixotropy of the structure of the silicon dioxide, once only the viscosity increase does not result in the anti-sedimentation effect. Because it is constituted of particles, silicon toxicological effects were investigated and, according to the inherent characteristics of the silicon dioxide particles, no dermal and oral absorption nor silicosis formation in humans and rats were observed; no eye irritation nor dermal and oral absorption in rabbits were observed, as well. The rat $L D_{50}$ was $3300 \mathrm{mg} / \mathrm{kg}$; proving the safety of the product used [39]. These characteristics were important and it became clear the increased efficiency of the drying process, especially in decreasing the adsorption of the powder in the drying of the spray dryer chamber, increasing the process yielding. Additionally, its association with arabic gum or modified starch, potentiated the silicon dioxide thixotropic effect allowing the suspension to be thick and slightly stable during the drying process. Reports have demonstrated the improved powder flowability, compressibility and compactibility not only of isolated compounds, but also of plant extracts [40-42].

Regarding the particle morphology, the two encapsulatings studied furnished particles with an agglomerate type [43] of rounded shape with rough surface. It has been reported that spherical particles are basically prepared using the spray method because the particles are produced from the droplets with a spherical shape, and the most stable shape for a droplet is the spherical form [44].

Both encapsulating systems were effective against S. aureus, whereas E. coli was resistant to them. Usually, propolis has activity against Gram-positive bacteria, such as S. aureus, Staphylococcus epidermidis, Streptococcus pneumoniae [45] and Streptococcus mutans [46]. Gram-negative bacteria, on the other hand, are often resistant to propolis. E. coli, a Gramnegative bacterium, is usually resistant to propolis samples from different geographical regions [45,47-49]. Nevertheless, other Gram-negative bacteria may be susceptible to propolis, like Haemophillus influenzae, which is more susceptible to Brazilian green propolis than S. aureus [45].

Noteworthy, reports evidence the maintenance of the antibacterial effect, as well as, of other biological activities, 
such as antioxidant, in microencapsulated propolis extracts [25]. Microencapsulated propolis extract obtained by complex coacervation presented inhibitory activity against $S$. aureus, around $200-400 \mathrm{mg} / \mathrm{mL}$ [25]. It is known that the inhibitory activity could be correlated with the amount of some compounds, mainly flavonoids. Therefore, the encapsulating system and the spray-drying conditions, proposed in this work, allowed to obtain a standardized propolis extract with high propolis and flavonoid content, as well as, with preserved biological activity.

\section{Conclusions}

This study evidenced different encapsulating systems led to different effects on propolis extract depending on the drying process parameters. Moreover, the system has to be chosen considering the properties and inherent limitations of active material to be encapsulated, as well as, information on the effects of interaction between the components of the formulations to finally determine the drying conditions. Thus, it was possible to determine that the encapsulating system A (propolis:arabic gum:silicon dioxide, 1.0:0.5:0.5) and B (propolis:modified starch:silicon dioxide, 1.0:0.5:0.5) and the spray-drying conditions allowed to obtain a standardized propolis extract with high propolis ratio, high flavonoid content and the expected amounts of artepillin C. These extracts were also able to keep the biological activities reported for propolis. These results opens perspectives to further obtain propolis-based pharmaceutical dosage forms.

\section{Competing interests}

The authors declare that they have no competing interests.

Authors' contributions
\begin{tabular}{|l|c|c|c|c|c|c|c|}
\hline Authors' contributions & FSM & APN & HSB & FMO & LAF & JKB & AAB \\
\hline Research concept and design & -- & -- & -- & -- & $\checkmark$ & $\checkmark$ & $\checkmark$ \\
\hline Collection and/or assembly of data & $\checkmark$ & $\checkmark$ & $\checkmark$ & -- & -- & -- & -- \\
\hline Data analysis and interpretation & $\checkmark$ & $\checkmark$ & $\checkmark$ & $\checkmark$ & $\checkmark$ & $\checkmark$ & $\checkmark$ \\
\hline Writing the article & -- & -- & -- & $\checkmark$ & -- & -- & $\checkmark$ \\
\hline Critical revision of the article & -- & -- & -- & -- & -- & $\checkmark$ & $\checkmark$ \\
\hline Final approval of article & -- & -- & -- & -- & -- & $\checkmark$ & $\checkmark$ \\
\hline Statistical analysis & $\checkmark$ & $\checkmark$ & -- & -- & -- & -- & -- \\
\hline
\end{tabular}

\section{Acknowledgement}

The authors are grateful to Ana Rita Costa-Machado and Paula Carolina Pires Bueno for valuable suggestions and for Coordenação de Aperfeiçoamento de Pessoal de Nível Superior (CAPES), Conselho Nacional de Desenvolvimento Científico e Tecnológico (CNPq), São Paulo Research Foundation - FAPESP (Brazil) and Apis Flora Indl. Coml. Ltda. for financial support and for granting research fellowships.

\section{Publication history}

EIC: James Radosevich, University of Illinois, USA. Received: 23-Apr-2015 Final Revised: 20-Jun-2015 Accepted: 03-Aug-2015 Published: 12-Aug-2015

\section{References}

1. Fischer G, Conceicao FR, Leite FP, Dummer LA, Vargas GD, Hubner Sde O,
Dellagostin OA, Paulino N, Paulino AS and Vidor T. Immunomodulation produced by a green propolis extract on humoral and cellular responses of mice immunized with SuHV-1. Vaccine. 2007; 25:1250-6. | Article | PubMed

2. Bankova VS, Castro SL and Marcucci MC. Propolis: recent advances in chemistry and plant origin. Apidol. 2000; 31:3-15. | Article

3. Burdock GA. Review of the biological properties and toxicity of bee propolis (propolis). Food Chem Toxicol. 1998; 36:347-63. | Article | PubMed

4. Wang L, Mineshita S, Ga I, Shigematsu T and Matsuno T. Antiinflammatory effect of propolis. Jpn J Pharmacol Ther. 1993; 24:223-4.

5. Machado JL, Assuncao AK, da Silva MC, Dos Reis AS, Costa GC, Arruda Dde S, Rocha BA, Vaz MM, Paes AM, Guerra RN, Berretta AA and do Nascimento FR. Brazilian green propolis: anti-inflammatory property by an immunomodulatory activity. Evid Based Complement Alternat Med. 2012; 2012:157652. | Article | PubMed Abstract | PubMed Full Text

6. Hori JI, Zamboni DS, Carrao DB, Goldman GH and Berretta AA. The Inhibition of Inflammasome by Brazilian Propolis (EPP-AF). Evid Based Complement Alternat Med. 2013; 2013:418508. | Article | PubMed Abstract | PubMed Full Text

7. Rocha BA, Rodrigues MR, Bueno PCP, Costa-Machado ARM, Vaz MMOLL, Nascimento AP, Barud HS and Berretta-Silva AA. Preparation and thermal characterization of inclusion complex of Brazilian green propolis and hydroxypropyl- $\beta$-cyclodextrin. J Therm Anal Calorim. 2012; 108:87-94. | Article

8. Kumazawa S, Hamasaka T and Nakayama T. Antioxidant activity of propolis of various geographic origins. Food Chem. 2004; 84:329-39. | Article

9. Salomao K, de Souza EM, Henriques-Pons A, Barbosa HS and de Castro SL. Brazilian Green Propolis: Effects In Vitro and In Vivo on Trypanosoma cruzi. Evid Based Complement Alternat Med. 2011; 2011:185918. | Article | PubMed Abstract | PubMed Full Text

10. Pontin K, Da Silva Filho AA, Santos FF, Silva ML, Cunha WR, Nanayakkara NP, Bastos JK and de Albuquerque $S$. In vitro and in vivo antileishmanial activities of a Brazilian green propolis extract. Parasitol Res. 2008; 103:487-92. | Article | PubMed

11. Berretta AA, Nascimento AP, Bueno PC, Vaz MM and Marchetti JM. Propolis standardized extract (EPP-AF(R)), an innovative chemically and biologically reproducible pharmaceutical compound for treating wounds. Int J Biol Sci. 2012; 8:512-21. | Article | PubMed Abstract | PubMed Full Text

12. Berretta AA, de Castro PA, Cavalheiro AH, Fortes VS, Bom VP, Nascimento AP, Marquele-Oliveira F, Pedrazzi V, Ramalho LN and Goldman GH. Evaluation of Mucoadhesive Gels with Propolis (EPP-AF) in Preclinical Treatment of Candidiasis Vulvovaginal Infection. Evid Based Complement Alternat Med. 2013; 2013:641480. | Article | PubMed Abstract | PubMed Full Text

13. Chen J, Long $\mathrm{Y}$, Han $\mathrm{M}$, Wang $\mathrm{T}$, Chen $\mathrm{Q}$ and Wang R. Water-soluble derivative of propolis mitigates scopolamine-induced learning and memory impairment in mice. Pharmacol Biochem Behav. 2008; 90:441-6. | Article I PubMed

14. El-Sayed el SM, Abo-Salem OM, Aly HA and Mansour AM. Potential antidiabetic and hypolipidemic effects of propolis extract in streptozotocin-induced diabetic rats. Pak J Pharm Sci. 2009; 22:168-74. | Article I PubMed

15. Kitamura H, Naoe Y, Kimura S, Miyamoto T, Okamoto S, Toda C, Shimamoto $Y$, Iwanaga $T$ and Miyoshi I. Beneficial effects of Brazilian propolis on type 2 diabetes in ob/ob mice: Possible involvement of immune cells in mesenteric adipose tissue. Adipocyte. 2013; 2:227-36. | Article | PubMed Abstract | PubMed Full Text

16. Choi SS, Cha BY, lida K, Lee YS, Yonezawa T, Teruya T, Nagai K and Woo JT. Artepillin C, as a PPARgamma ligand, enhances adipocyte differentiation and glucose uptake in 3T3-L1 cells. Biochem Pharmacol. 2011; 81:925-33. | Article | PubMed

17. de Barros MP, Sousa JP, Bastos JK and de Andrade SF. Effect of Brazilian green propolis on experimental gastric ulcers in rats. J Ethnopharmacol. 2007; 110:567-71. | Article | PubMed 
18. Barros MP, Lemos M, Maistro EL, Leite MF, Sousa JP, Bastos JK and Andrade SF. Evaluation of antiulcer activity of the main phenolic acids found in Brazilian Green Propolis. J Ethnopharmacol. 2008; 120:372-7. I Article I PubMed

19. Health Canada monograph. Propolis-Buccal. 2014; 1-7. | Article

20. Bankova V. Chemical diversity of propolis and the problem of standardization. J Ethnopharmacol. 2005; 100:114-7. I Article I PubMed

21. Marquele FD, Stracieri KM, Fonseca MJ and Freitas LA. Spray-dried propolis extract. I: physicochemical and antioxidant properties. Pharmazie. 2006; 61:325-30. | Article | PubMed

22. Bruschi ML, Lara EH, Martins $\mathrm{CH}$, Vinholis $\mathrm{AH}$, Casemiro LA, Panzeri $\mathrm{H}$ and Gremiao MP. Preparation and antimicrobial activity of gelatin microparticles containing propolis against oral pathogens. Drug Dev Ind Pharm. 2006; 32:229-38. | Article I PubMed

23. Da Silva FC, Favaro-Trindade CS, De Alencar SM, Thomazini M and Balieiro JCC. Physicochemical properties, antioxidant activity and stability of spray-dried propolis. J ApiProd ApiMed Sci. 2011; 3:94-100. I Article

24. Da Silva FC, Da Fonseca CR, De Alencar SM, Thomazini M, Balieiro JCC, Pittia $P$ and Favaro-Trindade CS. Assessment of production efficiency, physicochemical properties and storage stability of spray-dried propolis, a natural food additive, using gum Arabic and OSA starch-based carrier systems. Food Bioprod Process. 2013; 91:28-36. | Article

25. Nori MP, Favaro-Trindade CS, De Alencar SM, Thomazini M, Balieiro JCC and Castillo CJC. Microencapsulation of propolis extract by complex coacervation. LWT-Food Sci Technol. 2011; 44:429-35. | Article

26. de Sousa JP, Bueno PC, Gregorio LE, da Silva Filho AA, Furtado NA, de Sousa $M L$ and Bastos JK. A reliable quantitative method for the analysis of phenolic compounds in Brazilian propolis by reverse phase high performance liquid chromatography. J Sep Sci. 2007; 30:2656-65. | Article | PubMed

27. Bruschi ML, Cardoso ML, Lucchesi MB and Gremiao MP. Gelatin microparticles containing propolis obtained by spray-drying technique: preparation and characterization. Int J Pharm. 2003; 264:45-55. | Article I PubMed

28. Box GEP, Hunter WG and Hunter JS. Statistics for experimenters: an introduction to design, data analysis and model building. John Wiley \& Sons: New York; 1978. | Article

29. Woisky RG and Salatino A. Analysis of propolis: some parameters and procedures for chemical quality control. J Apicult Res. 1998; 37:99-105.

30. Vendruscolo CW. Goma xantana e galactomanana (M. scrabella): desenvolvimento de matrizes hidrofílicas para liberação modificada de teofilina. Dissertação, Universidade do Vale do Itajaí, Itajaí. 2005. I Pdf

31. Prista LN, Alves AC and Morgado R. Tecnologia Farmacêutica. 4th ed. 1992; 2:1013.

32. Ansl é livro a referenci original: Ansel HC, Popovich NG, Allen Jr LV. Formas farmacêuticas e sistemas de liberação de fármacos, 6a ed. 2000; 177.

33. Clinical and Laboratory Standards Institute (CLSI). Methods for dilution antimicrobial susceptibility tests for bacteria that grow aerobically. Approved Standard, 9th ed. CLSI document M07-A9; 2012. I Pdf

34. Azevedo HMC. Encapsulação: Aplicação à Tecnologia de Alimentos. Alim Nutr. 2005; 16:89-97. | Pdf

35. Finotelli PV, Rocha-Leão MHM. Microencapsulation of ascorbic acid in maltodextrin and capsul using spray-drying. 2nd Mercosur Congress on Chemical Engineering and 4th Mercosur Congress on Process Systems Engineering; 2005.

36. Teixeira CCC, Teixeira GA and Freitas LAP. Spray Drying of Extracts from Red Yeast Fermentation Broth. Dry Technol. 2011; 29:342-50. | Article

37. Trubiano PC, Lacourse NL. Emulsionstabilizing starches. In: Risch SJ, Reineccius GA, editors. Flavor encapsulation. ACS Symposium Series: Washington; 1988; 45-54.

38. Evonik Industries. Sipernet and Aerosil in Spray Drying Applications. Technical Information TI 1365. I Pdf

39. Degussa creating essentials: Basics characteristics of Aerosil ${ }^{\circledR}$ Fumed silica, Technical Bulletin fines particles. $n^{\circ} 11$. I Pdf
40. Gallo L, Llabot J, Allemandi D, Bucalá V and Piña J. Influence of spraydrying operating conditions on Rhamnuspurshiana (Cáscara sagrada) extract powder physical properties. Powder Technol. 2011; 208:205-14. | Article

41. Gallo L, Piña J, Bucalá V, Allemandi D and Ramírez-Rigo MV. Development of a modified-release hydrophilic matrix system of a plant extract based on co-spray-dried powders. Powder Technol. 2013; 241:252-62. | Article

42. Souza $C$ and Oliveira W. Powder properties and system behavior during spray drying of Bauhinia forficata link extract. Dry Technol. 2006; 24:735-49. | Article

43. Walton DE and Mumford CJ. The effect of process variables upon the morphology of spray-dried particles. Trans IChemE. 1999; 77:442-60. | Article

44. Nandiyanto ABD and Okuyama K. Progress in developing spray-drying methods for the production of controlled morphology particles: From the nanometer to submicrometer size ranges. Adv Powder Technol. 2011; 22:1-19. | Article

45. Rocha BA, Bueno PC, Vaz MM, Nascimento AP, Ferreira NU, Moreno Gde P, Rodrigues MR, Costa-Machado AR, Barizon EA, Campos JC, de Oliveira PF, Acesio Nde O, Martins Sde P, Tavares DC and Berretta AA. Evaluation of a Propolis Water Extract Using a Reliable RP-HPLC Methodology and In Vitro and In Vivo Efficacy and Safety Characterisation. Evid Based Complement Alternat Med. 2013; 2013:670451. | Article | PubMed Abstract | PubMed Full Text

46. Asawahame C, Sutjarittangtham K, Eitssayeam S, Tragoolpua Y, Sirithunyalug $B$ and Sirithunyalug J. Antibacterial activity and inhibition of adherence of Streptococcus mutans by propolis electrospun fibers. AAPS PharmSciTech. 2015; 16:182-91. | Article | PubMed

47. Gardjeva PA, Dimitrova SZ, Kostadinov ID, Murdjeva MA, Peyche LP, Lukanov LK, Stanimirova IV and Alexandrov AS. A study of chemical composition and antimicrobial activity of Bulgarian propolis. Folia Med (Plovdiv). 2007; 49:63-9. I PubMed

48. Erkmen $\mathrm{O}$ and Ozcan MM. Antimicrobial effects of Turkish propolis, pollen, and laurel on spoilage and pathogenic food-related microorganisms. J Med Food. 2008; 11:587-92. I Article I PubMed

49. Kim YH and Chung HJ. The effects of Korean propolis against foodborne pathogens and transmission electron microscopic examination. $N$ Biotechnol. 2011; 28:713-8. | Article | PubMed

\section{Citation:}

Marquiafável FS, Nascimento AP, Barud HdS, Marquele-Oliveira F, de-Freitas LAP, Bastos JK and Berretta AA. Development and characterization of a novel standardized propolis dry extract obtained by factorial design with high artepillin $C$ content. $J$ Pharm Technol Drug Res. 2015; 4:1. http://dx.doi.org/10.7243/2050-120X-4-1 